\title{
RESPON ORANG KRISTEN TERHADAP PEMBERITAAN TELEVISI MENGENAI COVID-19
}

\author{
Oleh : \\ Simon \\ Sekolah Tinggi Teologi Salatiga \\ Email: simonpetrus45144@gmail.com
}

\begin{abstract}
ABSTRAK - Fokus artikel ini tentang respon orang Kristen terhadap pemberitaan televisi terkait Covid-19. Metode yang digunakan dalam penelitian ini adalah metode kualitatif deskriptif dengan pendekatan konten analisis. Hasil dari temuan artikel ini mengungkapkan bahwa pemberitaan televisi terkat Covid-19 lebih cenderung memberitakan angka-angka kematian dibandingkan dengan peliputan pasian yang sembuh. Kemudian dalam pemberitaan Covid-19 kepada pemirsa, narasi ketakutan sering digemakanoleh televisi dibandingkan narasi yang sifatnya menyemangati atau mengajak untuk bersikap optimisme. Selain itu, pemberitaan televisi dalam negeri masih lebih dominan mengekor pada pemberitaan media luar negeri. Berdasarkan fakta pemberitaan televisi tentang Covid-19 ini maka orang Kristen perlu meresponinya dengan hati dan pikiran tetap tenang yang diperoleh melalui perenungan Firman Tuhan dan iman yang teguh kepada Allah, melakukan pembanding informasi dari apayang ditonton, serta tidak ikut tersugesti atau terpengaruh.
\end{abstract}

Kata kunci: Berita, Covid-19, Televisi, Orang Kristen

ABSTRACT - Focus of this article about how Christians have responded to television coverage regarding Covid-19. This reseach used descriptive qualitative method with content analysis approach. The results of the findings of this article reveal that television coverage related to Covid-19 is more likely to report mortality rates than coverage of patients who recover. Then in Covid-19 reporting to viewers, narratives of fear are often echoed by television compared to narratives that are encouraging or inviting to be optimistic. In addition, domestic television coverage is still more dominant following foreign media coverage. Seeing this fact in relation to television coverage of Covid-19, Christians should respond with a calm heart and mind, make comparisons of information about what they watch, and not be suggested or influenced. This can be applied by Christians when the Word of God is firmly meditate on and believed and becomes a guide for their life.

Keywords: News, Covid-19, Television, Christians 


\section{PENDAHULUAN}

Memasuki awal tahun 2020, dunia digemparkan dengan berita timbulnya jenis penyakit baru yang dinamai World Health Organization (WHO) sebagai virus corona atau yang disingkat Covid-19. Berita penyebaran Covid-19 pun langsung begitu cepat tersiar keberbagai belahan benua oleh berbagai media seperti televisi, Facebook, Instagram dan lainnya. Seluruh media-media televisi memberitakan bahwa Covid-19 diyakini bermula penularannya di Provinsi Hubei, di pasar ikan Wuhan China. ${ }^{1}$ Organisasi kesehatan dunia (WHO) pun langsung mengumumkan bahwa wabah yang diyakini bermula timbul dari Cina ini ditetapkan sebagai virus yang tergolong berbahaya. WHO telah menyatakan bahwa dunia berada dalam pandemi global sejak kemunculan virus ini. ${ }^{2}$

Covid-19 adalah jenis virus yang menyebabkan penyakit pada binatang maupun manusia. ${ }^{3}$ Merebaknya virus ini turut mempengaruhi semua aspek tatanan kehidupan umat manusia secara mengglobal. Misalnya dalam bidang ekonomi akan berdampak pertumbuhan ekonomi melambat bahkan rentan karena aktivitas ekonomi mandek. Lembaga IMF mengatakan bahwa ekonomi dunia baru akan

\footnotetext{
${ }^{1}$ Adityo Susilo, "Coronavirus Disease 2019: Tinjauan Literatur Terkini” Jurnal Penyakit Dalam Indonesia,” Jurnal Penyakit Dalam Indonesia 7, no. 1 (2020): 45. 2 Dana Riksa Buana, “Analisis Perilaku Masyarakat Indonesia Dalam Menghadapi Pandemi Virus Corona (Covid-19) Dan Kiat Menjaga Kesejahteraan Jiwa," Sosial \& Budaya Syar-I 7, no. 3 (2020): 218.

${ }^{3}$ Adityo Susilo, "Coronavirus Disease 2019: Tinjauan Literatur Terkini" Jurnal Penyakit Dalam Indonesia," 46.
}

tumbuh $5,8 \%$ pada tahun $2021 .{ }^{4}$ Secara sosial kegiatan hang out dan nongkrong terhenti. Dalam bidang pendidikan berubah dari sistem konvensional menjadi belajar on line dari rumah. ${ }^{5}$ Dalam bidang keagamaan, ibadah di rumah ibadah dibatasi karena beresiko meningkatkan penyebaran Covid19 akibat kumpulan masa jemaat. Hal-hal ini menuntut ada kebijakan untuk mencegah penyebaran virus dengan mempertimbangkan sisi positif dan negatifnya dalam berbagai aspek. ${ }^{6}$

Wabah yang telah mengganggu seluruh aspek tatanan kehidupan umat telah menyebabkan kesulitan yang besar. Informasi Covid-19 yang begitu cepat tersampaikan ke pelosok dunia tentunya karena berbagai peran media. Media menjadi corong utama masyarakat mengetahui bagaimana perkembangan virus ini baik informasi angka kematian, kesembuhan dan penyebaran, masyarakat dapat menyaksikannya secara langsung dari rumah atau dari smarphone masing-masing. Di satu sisi masyarakat memang merasakan peranan media mengenai beritacovid-19 ini, namun jika tidak berhati-hati media juga berpotensi

\footnotetext{
4 "IMF: Ekonomi Global Akan Alami Masa Terburuk Akibat Virus Corona : Okezone Economy," accessed Mei 10, 2020,

https://economy.okezone.com/read/2020/04/15/20/21 99513/imf-ekonomi-global-akan-alami-masaterburuk-akibat-virus-corona.

${ }^{5}$ Frans Pantan \& Priskila Issak Benyamin, "Peran

Keluarga Dalam Pendidikan Anak Pada Masa Pandemi Covid-19," Kharisamta 3, no. 1 (2020): 15.

${ }^{6}$ Nur Rohim Yunus \& Annissa Rezki, “Kebijakan

Pemberlakuan Lockdown Sebagai Antisipasi Penyebaran Corona Virus Covid-19," Sosial \& Budaya Syar-I 7, no. 3 (2020): 227.
} 
menciptakan ketakukan bagi masyarakat yang menyaksikan tayangan berita pandemik ini.

Masifnya pemberitaan media televisi mengenai Covid-19 turut di dukung oleh Komisi Penyiaran Indonesia (KPI). Agung Suprio (Ketua KPI) menyarankan agar lembaga lembaga penyiaran berpartisipasi secara luas untuk menyiarkan tayangan terkait physical distancing untuk menghentikan penularan virus ini. ${ }^{7}$ Memang di satu sisi televisi berkewajiban melakukannya tugas kejurnalistikannya tentang peliputan wabah ini, namun jika tidak jeli mengamati pemberitaan televisi yang terus-menerus menayangkan, maka psikologis pemirsanya dapat terganggu seperti munculnya kuatir dan kecemasan akibat pengaruh berita televisi karena Covid19. Menurut Khatimah, media massa memiliki peran penting dalam perubahan perilaku dalam masyarakat. ${ }^{8}$ Iwan Joko Prasetyo mengatakan bahwa media dapat menggubah pendapat masyarakat tentang apa yang dianggap penting. Jadi media memiliki efek yang pengaruh yang besar, terutama berkaitan dengan proses belajar dan

\footnotetext{
7 “'KPI Minta Lembaga Penyiaran Masif Siarkan Penanggulangan \& Pencegahan Covid-19 : Okezone Nasional," accessed Mei 11, 2020, https://nasional.okezone.com/read/2020/04/20/337/22 02001/kpi-minta-lembaga-penyiaran-masif-siarkanpenanggulangan-pencegahan-covid-19.

${ }^{8}$ Husnul Khatimah, "Posisi Dan Peran Media Dalam Kehidupan Masyarakat," Tasamuh 16, no. 1 (2018): 133.
}

bukan dengan perubahan sikap dan pendapat. $^{9}$

Sebagian masyarakat menganggap pemberitaan media televisi terkait Covid-19 bukan lagi pada penyampaian informasi, namun sudah seperti menciptakan suasana yang horor serta tidak sehat bagi kejiwaan bahkan memunculkan keberatan para netizen dengan membuat tagar kampanye "matikan TV" sebagai bentuk protes mereka kepada media TV. Pendapat yang sama diberikan oleh Sanityastuti, bahwa saat ini siaran televisi (TV) telah membuat banyak protes dan kritikan termasuk dalam bentuk membuat seminar dan pendirian lembaga literasi media yang dilaksanakan oleh perguruan-perguruan tinggi. ${ }^{10}$

Fokus dari pembahasan artikel ini bukan terletak pada Covid-19, tetapi tulisan ini menyoroti bagaimana pemberitaan televisi mengenai Covid-19. Orang Kristen tentu ikut menonton tayangan berita yang disiarkan oleh televisi. Bagimana orang Kristen meresponi tayangan berita Covid-19 yang disiarkan oleh televisi? Dua hal itulah yang akan diuraikan pada tulisan ini. Adapun tujuan dari pembahasan artikel ini untuk mengajarkan agar pembaca bersikap kritis dan analitis pada tayangan berita yang ditonton. Dengan membahas ini ada kontribusi atau manfaat yang diperoleh bagi pembaca untuk lebih berhati-hati dalam mencerna setiap pemberitaan di TV terkait berita Covid-19.

\footnotetext{
${ }^{9}$ Iwan Joko Prasetyo, "Pengaruh Pemberitaan Media Massa Terhadap Kredibilitas Pemimpin Simbolik Keagamaan,” Jurnal Komunikasi 8, no. 2 (2016): 13. ${ }^{10}$ Marfuah Sri Sanityastuti, "Literasi Media : Upaya Menyikapi Tayangan Televisi” 7, no. 2 (2014): 25.
} 


\section{METODE PENELITIAN}

Abdurahman mengatakan bahwa penelitian adalah aktivitas untuk mencari jawaban yang benar terhadap suatu persoalan dalam rangka mendapatkan pengetahuan ilmiah tertentu yang berguna secara teoritis maupun praktis. ${ }^{11}$ Peneliti menggunakan metode kualitatif deskriptif dengan pendekatan kontent analisis. Peneliti akan akan menguraikan secara mendetail isi tentang informasi yang ada dalam media massa dan televisi. Analisis isi merupakan metode yang meliputi semua analisis mengenai isi teks, tetapi disisi lain analisis isi juga digunakan dalam pendeskripsian pendekatan analisis yang khusus. ${ }^{12}$ Menurut Zahrotunnimah metode analisis isi adalah cara pengambilan kesimpulan dengan mengenali berbagai karakteristik khusus suatu pesan secara objektif, sistematis dan generalis. Tayangan pemberitaan tevelesi terkait Covid-19 dilihat dan diamati peneliti, kemudian dikaitkan dengan tanggapan masyarakat (netizen) terhadap berita yang disiarkan untuk memperoleh sebuah keobjektifan.

${ }^{11}$ Ating Somantri Maman Abdurahman, Sambas Ali Muhidin, Dasar-Dasar Metode Statistika Untuk Penelitian (Bandung: CV Pustaka Setia, 2011), 13.

${ }^{12}$ Zahrotunnimah, "Langkah Taktis Pemerintah Daerah Dalam Pencegahan Penyebaran Virus Corona Covid-19 Di Indonesia," Sosial \& Budaya Syar-I 7, no. 3 (2020): 250 .

\section{HASIL DAN PEMBAHASAN}

\section{Posisi Televisi dalam Kehidupan Masyarakat}

Semenjak masa Orde Baru berlalu dan beralih ke era reformasi, laju pertumbuhanmedia televisi semakin menanjak pertambahannya. Dengan bertambahnya jumlah stasiuntelevisi pasca reformasi, monopoli media tidak berlaku lagi dimasa kini, karena masyarakat mempunyai berbagai pilihan stasiun televisi yang disukai. Nizomi mengatakan bahwa padamasa Orde Baru, hanya ada TVRI, namun di era reformasi muncul banyak stasiun swasta berskala nasional (RCTI, SCTV, ANTV, Indosiar, TV One dan lainnya) serta aneka stasiun televisi di daerah. Hal ini memberi banyak pilihan kepada masyarat baik jenis konten tayangannya maupun konten hiburan atau informasi. 13 Stasiun televisi turut mempengaruhi seluruh aspek kehidupan dalam masyarakat di masa kini. Televisi kini bukan lagi sebatas pengusir kebosanan dihati, tetapi telah menjelma membentuk tatanan aspek hidup masyarat Indonesia. Ini pula yang diungkapkan oleh Nurchayati bahwa Televisi pada saat ini bukan lagi barang mewah yang hanya dapat dimiliki oleh sebagian orang. Seiring perkembangan teknologi serta daya kemampuan finansial masyarakat makin meningkat, membuat televisi dapat dihadirkan disetiap rungan dalam keluarga. Dengan kemudahan televisi

\footnotetext{
${ }^{13}$ Khairin Nizomi, "LITERASI MEDIA (Analisis Isi Terhadap Tayangan Televisi Pesbukers)," JIPI (Jurnal Ilmu Perpustakaan Dan Informasi) Vol.3 No. 1 (2018): 86.
} 
yang didapatkan oleh masyarat menyebabkan intensitas keseharian menonton tidak bisa lepas dari televisi. Televisi mampu menarik perhatian masyarakat dari semua kalangan dengan berbagai variasi program acara yang disuguhkan. ${ }^{14}$

Posisi televisi dalam kehidupan masyarat telah mempengaruhi berbagai aspek manusia. Dalam aspek ekonomi menciptakan percepatan perputaran uang karena gaya hidup masyarakat menjadi semakin konsumtif. Ini dikarenakan tayangan-tayangan iklan TV membuat masyarakat menjadi konsumtif yang memanjamakan mata oleh produk iklan. Dengan makin konsumtif, maka pergerakan ekonomipun menjadi cepat karena perputaran barang dan uang berjalan ditengah masyarakat. Menurut Rosana, media berguna dalam melindungi informasi, menghibur, membentuk opini masyarakat, mentransfer budaya, mempromosikan barang dan jasa, mendidik dan bersosialisasi. ${ }^{15}$

Tidak mengherankan jika dimasa kini, para pemilik stasiun televisi berlombalomba menayangkan acara yang tujuan utamanya mendatangkan keuntungan secara besar-besaran. Sebab media televisi merupakan ladang bisnis yang menjanjikan. Kecenderungan bisnis media sekarang

${ }^{14}$ Zulin Nurchayati, "Televisi Sebagai Media Komunikasi Massa Dan Pengaruhnya," Masyarakat Telematika Dan Informasi 16, no. 2 September (2015): 59.

${ }^{15}$ Anita Septiani Rosana, “Akses Informasi Melalui Media Massa Di Era Globalisasi (Persfektif Etika Media)," Jurnal Gema Eksos 5, no. 1 (2009): 53. dimasa kini dianggap sebagai bisnis umum untuk mengeruk keuntungan yang menggunung tanpa perlu mempertimbangkan isi dan muatan yang terkandung di dalam konten media itu. Sesungguhnya isi dan muatan konten medialah yang bernilai penting bagi kehidupan masyarakat. Jika media hanya bertujuan untuk pengerukan profit, maka media menjadi alat penjajahan abad modern ini. $^{16}$

Posisi televisi dalam kehidupan masyarat juga turut mempengaruhi kondisi psikologis penontonnya. Kondisi psikologis yang dimaksud suasana pikiran yang penat dapat disegarkan dari tayangan hiburan yang disajikan oleh televisi. Kondisi hati yang galau atau murung dapat menjadi riang gembira dengan konten acara yang membuat penontonnya tertawa. Setuju atau tidak setuju televisi dapat mengubah suasana psikologis penontonnya ke suasana berbagai hal melalui acara yang disiarkan. Di satu sisi ada kalanya memang televisi memberikan hiburan yang menyenangkan bagi perasaan jiwa, namun televisi juga dapat mengubah suasana perasaan psikologis seseorang yang mengarah pada hal negatif. Contohnya tayangan televisi yang berunsur kekerasan, maka itu berpotensi membuat penonton menjadi orang yang agresif karena secara perlahan tayangan yang ditonton dapat mengubah perilakunya. Tayangan televisi mengekspos kekerasan menjadi salah satu faktor pemicu perilaku agresif pada anak

\footnotetext{
${ }^{16}$ Ahmad Toni, "Bisnis Media : Pasca Matinya Televisi Nasional Dalam Perspektif Jurnalistik," Jurnal Komunikasi 8, no. 1 (2016): 38.
} 
usia dini hingga SMA. Terlebih lagi bila ditonton dalam waktu yang lama, dengan kualitas tayangan yang tidak berisfat edukasi, dapat merusak pembinaan moral anak. Andreas Dwi Atmoko, Zainal Munir, and Gilang Ramadhan mendukung bahwa tayangan televisi yang memperlihatkan kekerasan membentuk perilaku agresif anak. ${ }^{17}$

Peran televisi dalam kehidupan spiritual masyarat juga berpengaruh. Hadirnya berbagai stasiun televisi menyiarkan acara siraman rohani baik kajian agama Muslim, Kristen beserta agama lainnya. Acara-acara siraman rohani tersebut tentunya berdampak pada spiritual masyarakat karena menambah pengetahuan tentang agama masing-masing lewat tayangan tersebut. Tayangan religi di televisi umumnya berisi hal-hal keagamaan yang menampilan relasi manusia dengan Tuhan Yang Maha Esa harus didominasi penyampaian sisi positif dalam cerita. Tayangan dengan cerita bernuansa keagamaan menjadi pilihan penting untuk mengajak masyarakat mengingat kepada Tuhan serta berperilaku sopan dalam masyarakat. 18 Dengan bertambahnya pengetahuan tentang agama dan mengajak pemirsanya untuk dekat kepada Sang

\footnotetext{
${ }^{17}$ Andreas Dwi Atmoko, Zainal Munir, and Gilang Ramadhan, "Pengaruh Menonton Tayangan Televisi Terhadap Perilaku Agresif Pada Anak Prasekolah," Jurnal Keperawatan Profesional (JKP) 7, no. 1 (2019).

18 AA Kusumadinata Utri Indah Lestari, Undang Suryatna, "Pengaruh Menonton Tayangan Ftv Kuasa Ilahi Terhadap Perilaku Masyarakat," Jurnal Komunikatio 4, no. 1 (2018): 55.
}

pencipta yang teraplikasikan dalam perbuatan, bukankah itu menunjukkan betapa posisi media dalam tatanan spiritualitas terlihat jelas.

\section{Pemberitaan Televisi Terkait Covid-19}

\section{Fokus Pada Pemberitaan Angka Kematian}

Semenjak presiden Jokowi mengumumkan kasus perdana Covid-19 di Indonesia pada 2 Maret 2020, maka pemberitaan televisi tidak pernah berhenti sampai sekrang. Secara keseluruhan media televisi di Indonesia secara serentak memborbadir siaran berita Covid-19 kepada masyarat di seluruh tanah air tanpa hentinya. Televisi selalu upto date dari pagi sampai malam menyiarkan apa saja yang berkaitan dengan Covid-19. Porsi pemberitaan televisi terhadap angka kematian dinilai lebih besar dibandingkan dengan porsi pemberitaan yang sembuh. Padahal realitanya angka kesembuhan lebih besar dibandingkan dengan angka kematian karena Covid-19, akan tetapi yang paling besar disorot oleh media TV justru angka-angka kematian. Jika diperhatikan tayangan media televisi terkait pemberitaanCovid-19 maka hampir semua orang ketakutan dengan covid akibat propaganda yang dibesar-besarkan oleh media, tiap hari semua media mengutif jumlah korban terinfeksi dan kematian akibat covid, seharusnya media-media juga melakukan investigasi dan komparasi sendiri untuk memberi informasi yang lebih mencerahkan kepada publik.

Berita yang lebih cenderung mengenai jumlah kematian karena Covid-19 kepada penonton, dikuatirkan dapat 
menyebabkan masyarakat menjadi makin resah dan kuatir. Anwas mengemukakan bahwa saat ini masyarakat awam cenderung resah dan komplain karena tayangan televisi lebih cenderung menyajikan acara-acara acara berbau keglamoran, berita yang bersifat takut, unsur kekerasan, seksualitas, serta perilaku yang menyimpang. Melihat situasi ini, pihak stasiun televisi tidak dapat diharapkan untuk menyajikan acara yang berkualitas. Dengan dalih pada kebebasan, demokrasi, serta kepentingan bisnis, seolah pihak stasiun televisi membenarkan berbagai tayangan apapun padahal tujuannya untuk menarik penonton. ${ }^{19}$

Televisi boleh-boleh saja memberitakan informasi tentang angka kematian Covid-19, namun kurang elok jika hampir keseluruhan media TV secara beramai ramai mengedepankan peliputan kematian Covid-19 kepada pemirsanya. Sebagai contoh misalnya, tenaga medis yang meninggal akan disorot secara serentak oleh semua media televisi. Walau tenaga medis salah satu garda terdepan dalam menangani wabah ini, tetapi memberitakan dengan porsi jam tayang besar kurang lah tepat. Lebih baik media televisi memberitakan atau menyoroti pasien-pasien yang sembuh supaya itu menjadi spirit bagi penonton di rumah. Semestinya media massa perlu memahami bahwa mereka dapat menjadi kekuatan yang riil untuk membentuk dan mengarahkan seseorang maupun masyarakat. Sebab media sangat dekat

${ }^{19}$ Oos M Anwas, "Budaya Literasi Media Televisi Culture of Television Media Literacy," Jurnal Teknodik 16, no. 4 (2012): 424. dengan kehidupan masyarat sehari-hari, bahkan hampir seluruh hidup orang banyak dibenamkan karena media seperti televisi, radio atau internet. Ini artinya sepertiga dari hidup kita dihabiskan dengan membenamkan diri dalam media sehingga mempengaruhi kemampuan kita dalam berpikir, berbicara, berinteraksi dengan orang lain bahkan mimpi dan kesadaran akan identitas kita dibentuk oleh media. ${ }^{20}$

\section{Dominan Narasi Ketakutan Dibandingkan Narasi Optimisme}

Berita yang disiarkan televisi kepada penonton terkait Covid-19 muatan narasinarasi ketakutan yang lebih dominan digemakan dibandingkan dengan narasinarasi optimisme di masa pandemik ini. Penilain ini didasarkan pada ungkapan para netizen terkait isi narasi berita yang disiarkan. Pendapat musisi Jerinx mengemukakan bahwa pemberitaan televisi tentang Covid-19 seragam semua yang sifatnya menakut-nakuti. Sebagai corong utama dalam penyampaian informasi ke publik, TV harus andil dalam membangun pola pikir masyarat untuk bersikap optimisme apalagi disituasi menakutkan bagi sebagian orang.Televisi harus menyadari setiap berita yang mereka sampaikan yang sifanya berbentuk audio visual mampu mempengaruhi suasana psikologis para penontontnya. Menurut Artha, televisi itu ibarat jendela terhadap dunia, yang membantu menciptakan gambar di dalam jiwa seseorang. Gambar yang dilihat itulah

\footnotetext{
${ }^{20}$ Abu \& Ahmadi, Psikologi Sosial (Jakarta: Rineka Cipta, 2007), 49.
} 
yang akan membentuk bagian penting cara seseorang belajar dan menilai persepsi tentang dirinya. Apa yang kita peroleh melalui pengamatan pada jendela itu dipengaruhi oleh berbagai faktor, yaitu lama waktu menonton dan mengikuti siaran, usia, kemampuan khusus seseorang dan keadaan seseorang pada waktu itu. ${ }^{21}$

Sebagai contoh model narasi ketakutan yang dibangun oleh media televisi kepada penonton dengan menyatakan bahwa covid-19 tidak akan pernah hilang dari muka bumi. ${ }^{22}$ Contoh lain dari narasi ketakutan yang sering digemakan televisi akan ada korban gelombang kedua dari covid-19 yang mungkin jumlah kematian maupun terpapar lebih banyak dari yang sebelumnya. ${ }^{23}$ Menyiarkan pemberitaan Covid-19 dengan membagun narasi yang menakuti, bukankah berpotensi menyebabkan masyarakat menjadi semakin takut bahkan berpotensi hilang harapan untuk hidup normal sebelum Covid-19 muncul. Seharusnya dengan situasi yang genting begini, televisi memerankan fungsinya dengan memperbanyak narasi optimisme dalam penyiaran berita Covid-19. Sebab, semakin sering masyarakat menonton berita-berita yang sifatnya negatif, maka psikonalitas individu (penonton) akan semakin cenderung negatif dan mendorong dia untuk bersugesti bahwa ia terkena Covid-19. Sedana dengan itu Praditya

${ }^{21}$ Dewi Juni Artha, "Pengaruh Pemilihan Tayangan Televisi Terhadap Perkembangan Sosialisasi Anak," Jurnal EduTech 2, no. 1 (2016): 22.

${ }^{22} \mathrm{https}: / / \mathrm{www}$. youtube.com/watch?v=zb0VUUoEx3 M(Dikses 11 Agustus 2020, pukul 10. 45 WIB)

${ }^{23} \mathrm{https}: / /$ www.youtube.com/watch?v=SExz5Ue-S_M (Diakses 11 Agustus 2020, pkl 11. WIB). berkata bahwa kekerasan dalam berita televisi dapat mempengaruhi penontonnya untuk menjadi lebih agresif. Adegan kekerasan yang realistik atau nyata akan menghasilkan agresi di kemudian hari, apalagi bila adegan tersebut ditampilkan secara jelas dan hidup sehingga menarik perhatian penuh dari para penonton. ${ }^{24}$

Apabila media membangun narasi yang bersifat optimisme kepada penonton, setidaknya ada semacam keyakinan kepada pemirsa serta bertambah semangat juang dan terbangun harapan positif untuk menghadapi keadaan hidup di masa yang sukar. Hal itu dapat berdampak pada meningkatkan imunitas tubuh karena menyerap informasi yang positif oleh pikiran. Karena dengan imunitas tubuh yang kuatlah sebagai salah satu pencegahan serta mempercepat proses penyembuhan bila sudah terpapar. Adapun contoh narasi-narasi optimisme yang dapat diberitakan oleh televisi dengan mewawancarai pasien-pasien yang sembuh dari Covid-19. Televisi memberikan porsi penanyangan berita dengan mengedepankan narasumber-narasumber yang mengajak pemirsanya untuk tidak perlu takut, namun tetap berpola hidup sehat. Dengan membangun narasi optimisme kepada penonton, maka secara alamiah sikap optimisme masyarakat terbangun, bukan malah rasa cemas yang ditimbulkan dari tayangan berita. Mengapa hal ini perlu dilakukan karena media adalah salah satu entitas terkuat dibumi ini. Selain membentuk

\footnotetext{
${ }^{24}$ \& Avin Fadilla Helmi L. Dion Praditya, Supra Wimbarti, "Pengaruh Tayangan Adegan Kekerasan Yang Nyata Terhadap Agresivitas," Jurnal Psikologi 1, no. 1 (1999): 52.
} 
dan mengarahkan individual atau golongan, media dekat itukepada kehidupan manusia sehari-hari,dan menyentuh setiap aspek keberadaan manusia baik itu hal berpikir, berbicara, berinteraksi dengan orang lain bahkan mimpi dan kesadaran akan identitas. ${ }^{25}$

Dengan membangun narasi yang membuat takut penonton oleh pemberitaan televisi terkait pemberitaan Covid-19, itu dapat menyebabkan masyarat menjadi makin stress dan panik. Memang media televisi bukanlah suatu hal yang realitas, akan tetapi media dapat membantu dalam menciptakan dan mempengaruhi realitas bagi masyarakat dan setiap pribadi. Fabriar mengemukakan bahwa isi media massa merupakan konsumsi otak bagi pemirsa, sehingga akan mempengaruhi realitas subjektif pelaku dalam berinteraski masyarakat. Gambaran tentang realitas yang dibentuk oleh isi media massa inilah yang nantinya mendasari respon dan sikap khalayak terhadap berbagai objek sosial. ${ }^{26}$

\section{Tayangan Televisi Masih Berpatokan Kepada Pemilik Modal}

Tingginya minat masyarakat terhadap televisi karena sifat kolaboratif audio dan gambar sehingga dapat melihat serta mendengar segala percakapan yang disampaikan secara langsung dengan alat indera. Hal ini ditunjang oleh globalisasi teknologi informasi dan jaminan penyelenggaraan kegiatan pengelolaan

${ }^{25}$ Abu \& Ahmadi, Psikologi Sosial, 49.

${ }^{26}$ Silvia Riskha Fabriar, "Etika Media Massa Era Global," An-Nida : Jurnal Komunikasi Islam 6, no. 1 (2014): 74. televisi di Indonesia oleh pemerintah. Pemilik modal merespon ini sebagai peluang bisnis yang menjanjikan, sehingga mereka memilih berinvestasi dalam bisnis pertelevisian, hal ini ditandai dengan bermunculannya televisi yang mengudara baik berskala nasional maupun lokal yang dimiliki pihak swasta. ${ }^{27}$ Televisi sudah menjadi media yang paling digemari hampir semua lapisan masyarakat. Di samping televisi menawarkan program hiburan yang disukai sebagain masyarat, didukung pula jangkauan frekuensi penyiaran setiap stasiun televisi hampir merata ke berbagai pelosok di tanah air. Inilah membuat masyarat menjadi lebih mudah menikmati setiap setiap tayangan televisi.

Bila mengamati acara-acara yang ditayangkan oleh pertelevisian, konten acara yang disiarkan masih cenderung mengarah pada kepentingan pemilik modal. Apabila konten tayangan televisi tidak terlalu mendatangkan keuntungan yang besar, pemilik stasiun televise akan dengan mudah mengintervensi kru pembuat acara. Ketika stasiun televisi dikuasai oleh pemilik modal, maka kepentingan konsumen bisa dipinggirkan oleh mereka. Pemilik modal lebih fokus pada profit melalui iklan dan karena itu merelak melakuka penyesuaian acara-acara yang ditayangkan demi profit. ${ }^{28}$

\footnotetext{
${ }^{27}$ Alifia Pradyanti\& Nisfa Siti Elfianti Hidayah Azwar, "Etika Dalam Program Hiburan Televisi: Analisis Program Hiburan Waktu Indonesia Bercanda Net Tv"," Journal of Digital Education Communication 1, no. 2 (2018): 90-91.

${ }^{28}$ Redatin Parwadi, "Pengaruh Penggunaan Media Televisi Terhadap Penyimpangan Nilai Dan Perilaku Remaja (Kekerasan, Seks, Dan Konsumtif) Di Kota
} 
Kuatnya intervensi sipemilik modal atas stasiun televisi terhadap konten acara yang disiarkan, menandakan para kru atau karyawan yang bekerja di televisi tidak punya kebebasan untuk menyalurkan ideidenya terhadap isi konten yang disiarkan di televisi. Walau mungkin ide itu sifatnya mengedukasi atau memberi pencerahan, namun bila konten acara itu tidak mendatangkan keuntungan yang besar maka itu tidak diprioritaskan ole pemilik modal.

Jika dikaitkan dengan pemberitaan mengenai Covid-19, bisa dinilai pemilik modal turut andil dalam penyiaran berita mengenai pandemik ini. Dalam bisnis media, apabila suatu berita atau peristiwa itu sedang booming, biasanya media-media akan berlomba-lomba menjadikan itu sebagai berita utama. Covid-19 merupakan berita yang sedang boming di masa kini, karena covid-19 sedang booming maka televisi akan tetap membuat hal ini sebagai konten utama dalam penyiaran mereka. Televisi mengedepankan berita Covid-19 sebagai topik utama karena media membaca apa yang menjadi pangsa pasar utama yang laku bagi penonton. Apabila suatu peristiwa atau kejadian sedang disorot oleh masyarat, media akan menyiarkanya di stasiun televisi masing-masing. Pemilik modal tentu memperhatikan hal ini untuk bisa memanen untung dari tayangan berita yang disiarkan melaluii pemasukan dari iklan. Karman mengemukakan salah satu aspek yang tidak sesuai dengan teori normatif adalah praktik monopoli dalam industri media massa, dan

Yogyakarta," Jurnal Sosiohumaniora 7, no. 1 (2005): 37. penyeragaman konten. Seyogianya media mengedepankan prinsip diversity of ownership dan plurality of content. Sehingga individu dan komunitas memiliki akses yang sama kepada media. Namun, praktik monopoli, oligopoli, konglomerasi menjadi penghambat bagi terlaksananya normanorma oleh media. ${ }^{29}$

\section{Berita Covid-19 Selalu Mengekor Kepada Media Luar}

Apabila menyaksikan tayangan berita televisi dalam negeritentangi Covid-19, maka isi siaran yang ditayangkan hampir selalu seragam dengan pemberitaan media luar negeri. Keseragaman isi berita televisi lokal dengan media luar negeri, dapat dikatakan sebagai berita yang mengekor. Maksudnya berita apa yang disiarkan oleh media luar mengenai covid-19, berita itu juga yang disampaikan oleh per-televisian tanah air. Contoh isi pemberitaan televisi di tanah air yang berkiblat pada luar negeri adalah mengenai ciri-ciri orang terpapar Covid-19, suhu tubuh yang tinggi, sesak nafas, disampaikan media luar ini juga yang disampaikan televisi dalam negeri. Jika media luar menyiarkan hal-hal apapun yang berkaitan dengan Covid-19, maka media tanah air pun akan menyiarkannya. Dengan menayangkan apa yang ditayangkan oleh media luar, bukankah itu kategori mengekor?

Apabila memperhatikan tayangan berita televisi dalam negeri terkadang asal

\footnotetext{
${ }^{29}$ Karman, "Monopoli Kepemilikan Media \& Lenyapnya Hak Publik," Jurnal Masyarakat Telematika Dan Informasi 5, no. 1 (2014): 71.
} 
jadi saja, bahkan siaran berita yang ditayangkan belum dapat diategorikan pada porsi profesionalisme ke-jurnalistikan. Contoh berita profesionalisme itu dapat dilihat dari produksinya. Misalnya sebelum penyiaran berita, televisi mempunyai berbagai reporter di berbagai daerah untuk melaporkan langsung dari lapangan kejadian apa yang terjadi dengan narasumber si roperter itu sendiri langsung memperoleh data dari tempat kejadian. Nyatanya stasiun televisi dalam memproduksi berita, reporter TV tidak selalu ada di lapangan. Televisi masih menggunkan jasa orang lain untuk hasil produksi beritanya. Demikian juga dalam pemberitaan Covid-19, produksi televisi hanya mengkopy dan menerjemahkannya kemudian disiarkan ke masyarakat. Sebagaimana pendapat Sanityastuti bahwa berita merupakan tayangan TV yang dinilai sesuai dengan fungsi utama media massa, tetapi bagaimana berita di TV kita? Setelah pemerintah melonggarkan peraturan tentang penyiaran, maka televisi-televisi swasta dapat memproduksi berita sendiri. Kebebasan yang diberikan pemerintah kepada pihak stasiun televisi berdampak pada bermunculanlah program-program berita TV swasta. Walau stasiun televisi bebas dalam memproduksi berita-berita, tetap saja biaya produksi mahal karena minimnya pemasukan dari iklan, akibatnya berita nasional pun hanya memuat aneka peristiwa di ibu kota negara. Sedangkan peristiwa daerah hanya menampilkan wilayah yang bisa dijangkau reporter TV tersebut. Modusnya reporter datang ke daerah yang sudah direkayasa mau masuk TV, jadi menutupi realitas sosial budaya masyarakat, disamping itu juga keterbatasan daya tilik dan kepekaan kameramen yang tidak terdidik sesuai bidangnya. ${ }^{30}$

Media televisi di tanah air boleh dikatakan masih mengekor pada isi berita yang disampaikan oleh media luar negeri khususnya mengenai berita covid-19. Apa yang disampaikan oleh media luar, maka itu juga yang akan disampaikan oleh media dalam negeri dengan hanya menerjemahkan kemudian disiarkan kepada penonton di rumah. Sisi baik seperti ini adalah updatenya masyarat Indonesia akan perkembangan berita Covid-19 secara mengglobal. Akan tetapi, sisi negatifnya bila hanya mengekor pada berita luar negeri mengenai pandemik ini, media tanah air akan sulit melacak apakah berita itu kredibel atau unsur kepentingan pemilik media. Selain itu bahayanya bila media tanah air selalu mengekor pada berita luar tentang covid-19, tidak mengetahui apa yang menjadi agenda atau motif pemilik modal TV luar mengenai berita Covid-19. Sebagaimana yang diungkapkan Karman bahwa Media massa di Amerika cenderung terkonsentrasi/terintegrasi ke dalam satu kepemilikan (monopoli/ konglomerasi). Pemilik televisi kabel umumnya adalah perusahaan-perusahaan yang juga dominan di surat kabar, majalah, buku, dan penyiaran. Motivasi dominasi yang dilakukan oleh media massa adalah untuk mendapatkan uang (profitability) dan pengaruh (media power). Dalam kondisi ini khalayak lemah,

\footnotetext{
${ }^{30}$ Sri Sanityastuti, "Literasi Media : Upaya Menyikapi Tayangan Televisi,” 27-28.
} 
halayak tidak memiliki kemampuan menciptakan perubahan atau mencegah kondisi yang memburuk atau praktik buruk media massa. Sistem yang monopolistik menyebabkan kondisi buruk. Di Amerika, sistem monopoli media massa menyebabkan power media tergadai/tersandera oleh kepentingan segelintir elit media. ${ }^{31}$ Sudah seharusnya para pemilik stasiun televisi nasional berdikari sendiri dalam penyajian berita baik secara nasional maupun ditingkat internasional.

\section{Respon Orang Kristen Terhadap Tayangan Berita Covid-19}

\section{Hati Dan Pikiran tetap Tenang}

Kebijakan pemerintah menghimbau masyarakat untuk tetap di rumah (stay at home) mau tidak mau membuat kita menjadi lebih banyak waktu menonton televisi. Dengan menonton televisi, berita Covid-19 lebih banyak dilihat oleh masyarat untuk mengikuti bagaimana perkembangan pandemik ini. Orang percaya (Kristen) perlu cermat dan bijak dalam meresponi setiap berita yang disiarkan oleh televisi apalagi mengenai berita Covid-19. Hendaknya orang Kristen meresponi tontonan berita Covid-19 yang dilihatnya dengan hati dan pikiran yang tenang tanpa timbul kekuatiran atau kecemasan, walau dalam penyajian berita Covid-19 media mencoba membangun kondisi yang menakutkan. Karena akan sangat mungkin secara alamiah suasana hati dan pikiran manusia dapat ditimpa oleh rasa

${ }^{31}$ Karman, "Monopoli Kepemilikan Media \& Lenyapnya Hak Publik," 82-83. takut dan cemas dari apa yang dilihat. Bila indra mata selalu menonton berita Covid-19 yang cenderung ngeri dinarasikan oleh televisi, maka rasa cemas dapat timbul dengan sendirinya. Jika sudah timbul kecemasan, maka ketenangan hati dan pikiran akan terusik. Rasa cemas bisa datang dari dalam diri bisa juga dari luar. Contoh rasa cemas yang datang dari dalam saat punya masalah kesehatan, maka itu dapat menyebabkan seseorang menjadi cemas. Sementara rasa cemas yang ditimbulkan dari luar, bisa dari orang lain termasuk dari televisi yang menjadi pemberi informasi melalui gambar dan audio. Rofiqah mengatakan hal serupa bahwa dalam hidupsetiap individu tentu pernah mengalami kecemasan, baik itu berasal dari dalam diri seperti cemas terhadap suatu penyakit maupun yang berasal dari luar diri seperti ancaman dari orang lain. ${ }^{32}$

Menonton televisi erat kaitannya dengan mata, jika mata melihat hal-hal yang ngeri maka itu dapat mempengaruhi suasana hati dan pikiran. Sebab mata, telinga dan dan otak bereaksi ketika ada stimulus berupa gambar bergerak beserta suara yang mengikuti itu muncul ditonton. Walaupun menonton tayangan berita tentang Covid-19 yang disiarkan oleh televisi, hendaknya hati dan pikiran tetap tenang sebagaimana himbauan firman Tuhan. Ketengan hati dan pikiran ini tentu dihasilkan dari perenungan firman Tuhan melalui ayat Alkitab seperti

\footnotetext{
${ }^{32}$ Tamama Rofiqah, "Konseling Religius: Mengatasi Rasa Kecemasan Dengan Mengadopsi Terapi Zikir Berbasis Religio Psikoneuroimunologi," Jurnal Program Studi Bimbingan Konseling 3, no. 2 (2016): 76.
} 
Mazmur 91:1-16, yang memberikan jaminan pemeliharaan terhadap marabahaya. Paulus juga mengemukakan agar orang percaya jangan kuatir terkait hal apapun, tetapi menyatakannya Allah melalu doa dan permohonan dengan ucapan syukur. Damai sejahtera Allah, yang melampaui segala akal, akan memelihara hati dan pikiranmu dalam Kristus Yesus (Fil 4:6-7). Alkitab juga menulis "sungguh, Dialah yang akan melepaskan engkau dari jerat pengkap burung, dari penyakit sampar yang busuk" (Maz. 91:3).

Hati dan pikiran yang tenang didapatkan karena dilandasi mempercayai Tuhan dan firman-Nya sebagai kebenaran, firman yang dipercayai itulah merupakan penangkal tidak terjadinya rasa kuatir atau cemas dihati dan dipikiran sekalipun melihat tayangan televisi dengan narasi-narasi ketakutanakanCovid-19. Dengan bersikap tenang juga memperlihatkan bahwa orang percaya tidak dipengaruhi atau dikendalikan oleh keadaan, justru kita memperlihatkan intimnya hubungan kita dengan Allah. Sebab mereka yang memiliki hubungan yang erat dengan Allah, hati dan pikirannya dapat bersikap tenang sekalipun disituasi yang mencekam. Wijanarko mengemukakan jika hati mulai gelisah dan tidak terkendali, ambil napas dalam-dalam kemudian embuskan perlahan. Ulangi gerakan ini berulangkali. Akan lebih berarti jika anda mengulangi gerakan ini sembari menyebut nama Tuhan Yesus dalam hati. Hal ini menandakan bahwa kita mengingat Tuhan dalam kedaan ini. $^{33}$

\section{Tidak Tersugesti dengan Berita yang} Ditonton

Ketika kita menonton berita televisi mengenai Covid-19 iperlukan sikap kehatihatian terhadap tayangan berita tersebut. Apabila tidak waspada, berita televisi yang bersifat visual, berpotensi membuat seseorang tersugesti dari apa yang dilihat. Sugesti adalah pengaruh yang diterima oleh jiwa, sehingga perbuatannya tidak lagi berdasarkan atas pertimbanganpertimbangan cipta, rasa, dan karsanya. Dalam sugesti fungsi pikiran, perasaan, dan kemauan betul-betul dikesampingkan. Itulah sebabnya sugesti merupakan suatu desakan keyakinan kepada seseorang yang diterima tanpa pertimbangan secara mendalam. ${ }^{34}$ Sedangkan menurut Gerungan Sugesti adalah suatu proses di mana individu menerima suatu cara penglihatan atau pedoman-pedoman tingkah laku dari orang lain tanpa kritik terlebih dahulu. ${ }^{35}$

Pikiran manusia bisa tersugesti karena ada informasi yang didengar atau objek yang dilihat, informasi yang dilihat inilah yang ditayangkan oleh televisi dalam bentuk visual yang disaksikan oleh indra mata jasmani manusia. Bila dikaitkan dengan menonton berita Covid-19 yang

\footnotetext{
${ }^{33}$ Jarot Wijanarko, Hidup Produktif (Yogyakarta: ANDI, 2012), 36.

${ }^{34}$ Sayyid Abdul Basit Muhammad, The Spiritual Power Membangkitkan Kekuatan Paling Dahsyat Dalam Diri (Jakarta: Nakhlah Pustaka, 2008), 178. ${ }^{35}$ Gerungang WA, Psikologi Sosial (Bandung: Refika Aditama, 2009), 64.
} 
disiarkan oleh televisi, maka pribadi yang bersangkutan pikirannya dapat tersugesti karena dari hasil visual berita yang ditontonnya. Jika pikiran sudah tersugesti karena tayangan berita Covid-19, bisa menyebabkan rasa cemas dan kuatir. Pikiran adalah sebuah magnet bagi diri sendiri atau sering disebut sugesti. Pikiran yang positif dapat memberikan motivasi yang positif pula pada seseorang. Setiap sugesti yang diterima oleh seseorang akan memudahkan sugesti berikutnya. Maksudnya, setelah manusia sukses melakukan satu pekerjaan, pasti akan semakin termotivasi melakukan pekerjaan yang lebih sukses lagi. ${ }^{36}$

Ketika memiliki rasa takut terhadap sesuatu, maka rasa takut itu dapat mengarah pada kenyataan, rasa takut itu bisa timbul dari apa yang dilihat. Menonton berita Covid-19 yang disiarkan oleh televisi, tayangan berita itu dapat mengsugesti ranah pikiran penonton. Ini lah yang dimaksud oleh firman Tuhan, bahwa "karena yang kutakutkan, itulah yang menimpa aku, dan yang kucemaskan, itu yang mendatangi aku (Ay. 3:25). Ketika menonton berita Covid19 yang disiarkan di media, maka jangan sampai tayangan itu membuat orang percaya tersugesti, sebab apa yang ditakutkan itu dapat menjadi kenyataan. Ayub telah mengungkapkan apa yang ditakutkan dan dicemaskan itu berpotensi menimpa hidup orang percaya.

\section{Tidak Terlibat Menyebar Berita Hoax}

${ }^{36}$ Syamsul Rijal, "Hipnolinguistik: Bahasa Alam Bawah Sadar," Jurnal Pendidikan Progresif 5, no. 2 (2015): 194.
Keberagaman media massa di masa kini memang telah memanjakan masyarat dunia dengan segala tawarannya. Jika di masa lampu media komunikasi hanya bertumpu pada radio dan televisi, sekarang media komunikasi telah beragam kehadirannya dengan adanya Facebook, Twieter, Instagram Whatsap dan lainnya. Awalmya interaksi dalam bermedia berjalan hanya searah, dimana penikmat media saja yang bisa menikmati konten yang disajikan sumber media. Namun akibat kemajuan internet, kini orang awampun sudah bisa ikut mengisi konten di media tersebut dan membawa cara komunikasi baru di masyarakat. Media sosial hadir dan merubah paradigma berkomunikasi di masyarakat saat ini. Komunikasi tak terbatas jarak, waktu, ruang. 37

Berdasarkan pengamatan penulis di masa pandemik ini, ada sebagian orangorang Kristen bahkan pendeta yang hobi menyebarkan berita-berita Covid-19 tanpa disadari, pesan yang disebarkannya melalui Medsos dapat membuat sipenerima pesan menjadi takut maupun cemas. Tidak perlu menjadikan diri sebagai agen penyebar berita Covid-19 di Medsos, sebagaimana yang diperbuat oleh televisi. Lagi pula amat riskan berita yang disebarkan belum tentu kredibilitas kebenarannya. Sebagai contoh berdasarkan pengamatan penulis, beredar video yang memperlihatkan masyarat Ekuador banyak meninggal dan bergelimpangan di jalan raya karena Covid19. Video ini banyak di share diberbagai

\footnotetext{
${ }^{37}$ Errika Dwi Setya Watie, "Komunikasi Dan Media Sosial," The Messenger 3, no. 1 (2011): 69.
} 
media sosial termasuk pelakunya para jemaat dan para pendeta. Setelah video ini menjadi viral, media $\mathrm{CNN}$ pun merilis bahwa itu hanyalah hoax karena sudah diklarifikasi oleh negara Ekuador.

Tidak perlu menyibukkan diri untuk menyebarkan berita Covid-19 kepada orang lain, karena dimasa kini televisi telah menyajikan perkembangan berita Covid-19 kepada masyarakat. Lagi pula dengan menyebarkan berita-berita Covid-19 di media sosial, belum tentu sipenerima pesan menyukai berita yang sifatnya tidak menyenangkan. Angan sampai terjebak karena hobi share berita tetntang Covid-19 menjadi perpanjangan "tangan" media untuk menciptakan suasana kengerian sebagaimana yang diciptakan oleh televsi dalam pemberitaannya, walau mungkin berita yang disebarkan itu bersifat faktual. Bila menyebarkan berita faktual saja kurang pas, apalagi sampai terlibat dalam penyebaran berita hoax. Terlibat menyebarkan berita hoax sama saja menjadi penyebar kebohongan. Penyebar kebohongan merupakan pertentangan terhadap firman Allah, sebab Alkitab menulis "Janganlah engkau menyebarkan kabar bohong; janganlah engkau membantu orang yang bersalah dengan menjadi saksi yang tidak benar (Kel. 23:21).

\section{Melakukan Pembandingan Informasi}

Ketika menonton berita Covid-19 yang disiarkan oleh televisi, respon orang Kristen terhadap tayangan berita itu dapat dilakukan dengan cara membandingkan informasi. Melakukan pembanding informasi yang dimaksud di sini adalah jangan menelan secara bulat-bulat apa yang disampaikan oleh televisi terkait Covid-19. Melakukan pembanding informasi juga dapat diartikan dengan mencari berita dari media independen. Media independen yang dimaksud disini ialah isi beritanya tidak berorientasi pada bisnis, namun lebih kepada penyampaikan fakta dan informasi untuk mengedukasi masyarakat. Melalukan pembanding informasi juga bagian dari agar bisa mendapatkan informasi tentang apapun dari berbagai media, sehingga dapat menyimpulkan berita yang disampaikan televisi bersifat mengedukasi atau konten berita itu hanya mencari keuntungan.

Besarnya pengaruh pemberitaan televisi dewsa ini membuat masyarakat seharusnya untuk terbiasa melakukan literasi media. Budaya literasi bermedia yang baik salah satunya adalah membandingkan informasi yang disampaikan oleh media massa. Hal ini bertujuan agar khalayak mengambil tindakan atau memutuskan sesuatu ketika dia merespon informasi dari media massa, dilandasi pada pemikiran yang komprehensif. Dengan melakukan perbandingan informasi tersebut, artinya khalayak telah mendapatkan sebuah informasi dari banyak media massa dengan perspektif yang beragam. Sehingga khalayak mempunyai gambaran utuh mengenai informasi yang ia terima tersebut. Oleh sebab itu, khalayak akan dapat menilai kebenaran informasi dan kredibilitas penyampai informasi dahulu sebelum memutuskan untuk mengambil tindakan tertentu. Misalnya apakah mereka akan setuju atau tidak setuju dengan konten 
pemberitaan yang disampaikan oleh media massa. ${ }^{38}$

Melakukan pembandingan informasi merupakan langkah yang bijak dan tentunya berdasar dalam prinsip firman Tuhan.Yesus mengungkapkan kepada para murid-Nya, apabila ada yang berkata Mesis sudah datang, maka Yesus menghimbau agar jangan percaya. Ia berkata agar waspada supaya jangan ada yang menyesatkan, sebab banyak orang akan datang dengan memakai nama-Ku dan berkata: Akulah Mesias dan mereka akan menyesatkan banyak orang (Mat. 24:5-6). Paulus pun memperingatkan jemaat di Galatia, bahwa seandainya pun ada malaikat dari sorga memberitakan suatu injil yang berbeda dengan injil yang bertentangan yang diberitakan oleh Paulus mengenai Yesus Kristus maka terkutuklah ia (Gal. 1:8). Apa yang dituliskan oleh firman Tuhan di atas, prinsip utamanya mengajarkan agar tidak mudah percaya pada berita-berita yang sekalipun sepertinya benar, namun ternyata salah dan menyimpang. Karena berita yang seakan benar dianggap oleh mayoritas orang, justru bisa menyesatkan. Jika dikaitkan dengan pemberitaan Covid-19 yang ditonton oleh orang percaya, melakukan pembandingan informasi merupakan langkah yang bijaksana karena itu memperlihatkan sikap kristis dan analitis terhadap apa yang didengar dan dilihat sebelum diyakini.

\section{KESIMPULAN}

\footnotetext{
${ }^{38}$ Feri Ferdinan Alamsyah, Diana Amaliasari, and Imani Satriani, "Relasi Tingkat Kepercayaan Khalayak Terhadap Pemberitaan Di Media Massa Dengan Budaya Membandingkan Informasi," Jurnal Komunikasi 10, no. 2 (2018): 133.
}

Covid-19 yang timbul ditahun 2020 telah menyita perhatian penduduk dunia. Berbagai upaya dilakukan oleh setiap pemimpin negara agar penyebaran Covid-19 ini tidak menjangkiti lebih banyak orang. Pemberitaan televisi terkait Covid-19 dikritik sebagian masyarat, karena berita televisi dianggap tidak bersifat sebagai penyampai informasi atau edukasi. Namun berita televisi malah membuat penonton menjadi makin takut dan cemas. Hal ini dilihat dari penyiaran televisi terkait Covid19 lebih besar porsi pemberitaan angka kematian dibanding yang sembuh. Kemudian narasi-narasi berita yang sifatnya menakut-nakuti digemakan televisi untuk pemirsa dibanding narasi yang sifatnya membangun optimisme masyarakat akan keadaan sekarang.

Orang percaya (Kristen) yang ikut menyaksikan tayangan berita Covid-19, sudah sepautunya meresponi dengan kebijaksaan dan jangan sampai terbawa larut dalam suasana kengerian akan berita Covid19 yang disiarkan televisi, sehingga menimbulkan rasa cemas dan ketakutan. Tetapi responi berita itu dengan bersikap hati dan pikiran tenang, otak tidak tersugesti walau melihat tayangan covid-19, terlebih melakukan pembandingan informasi sebelum memutuskan informasi yang diterima oleh otak atau dilihat oleh mata yang nantinya dapat mempengaruhi kondisi psikologs kita sebagai orang percaya. Dengan keadaan sekarang ini hendaknya televisi tidak mengejar pemasukan iklan, namun berita yang ditayangkan membangun optimisme di tengah kesulitan berbagai hal yang dialami penonton. 


\section{RREFERENSI}

Alkitab. Jakarta: LAI, 2010.

Abu \& Ahmadi. Psikologi Sosial. Jakarta: Rineka Cipta, 2007.

Adityo Susilo. "Coronavirus Disease 2019:

Tinjauan Literatur Terkini" Jurnal

Penyakit Dalam Indonesia." Jurnal Penyakit Dalam Indonesia 7, no. 1 (2020).

Alamsyah, Feri Ferdinan, Diana Amaliasari, and Imani Satriani. "Relasi Tingkat Kepercayaan Khalayak Terhadap Pemberitaan Di Media Massa Dengan Budaya Membandingkan Informasi." Jurnal Komunikasi 10, no. 2 (2018).

Anita Septiani Rosana. "Akses Informasi Melalui Media Massa Di Era Globalisasi (Persfektif Etika Media)." Jurnal Gema Eksos 5, no. 1 (2009).

Anwas, Oos M. "Budaya Literasi Media Televisi Culture of Television Media Literacy." Jurnal Teknodik 16, no. 4 (2012).

Azwar, Alifia Pradyanti\& Nisfa Siti Elfianti Hidayah. "Etika Dalam Program Hiburan Televisi: Analisis Program Hiburan Waktu Indonesia Bercanda Net Tv",." Journal of Digital Education Communication 1, no. 2 (2018).

Buana, Dana Riksa. "Analisis Perilaku Masyarakat Indonesia Dalam Menghadapi Pandemi Virus Corona (Covid-19) Dan Kiat Menjaga Kesejahteraan Jiwa." Sosial \& Budaya Syar-I 7, no. 3 (2020).

Dewi Juni Artha. "Pengaruh Pemilihan Tayangan Televisi Terhadap Perkembangan Sosialisasi Anak."
Jurnal EduTech 2, no. 1 (2016).

Dwi Atmoko, Andreas, Zainal Munir, and Gilang Ramadhan. "Pengaruh Menonton Tayangan Televisi Terhadap Perilaku Agresif Pada Anak Prasekolah." Jurnal Keperawatan Profesional (JKP) 7, no. 1 (2019).

Errika Dwi Setya Watie. "Komunikasi Dan Media Sosial." The Messenger 3, no. 1 (2011).

Fabriar, Silvia Riskha. "Etika Media Massa Era Global.” An-Nida: Jurnal Komunikasi Islam 6, no. 1 (2014): 7085.

Frans Pantan \& Priskila Issak Benyamin. "Peran Keluarga Dalam Pendidikan Anak Pada Masa Pandemi Covid-19." Kharismta 3, no. 1 (2020).

"IMF: Ekonomi Global Akan Alami Masa Terburuk Akibat Virus Corona: Okezone Economy." Accessed August 15 , 2020. https://economy.okezone.com/read/202 0/04/15/20/2199513/imf-ekonomiglobal-akan-alami-masa-terburukakibat-virus-corona.

Iwan Joko Prasetyo. "Pengaruh Pemberitaan Media Massa Terhadap Kredibilitas Pemimpin Simbolik Keagamaan." Jurnal Komunikasi 8, no. 2 (2016).

Karman. "Monopoli Kepemilikan Media \& Lenyapnya Hak Publik." Jurnal Masyarakat Telematika Dan Informasi 5, no. 1 (2014). https://media.neliti.com/media/publicati ons/233799-monopoli-kepemilikanmedia-lenyapnya-hak-950f992e.pdf.

Khatimah, Husnul. "Posisi Dan Peran Media Dalam Kehidupan Masyarakat." 
Tasamuh 16, no. 1 (2018).

"KPI Minta Lembaga Penyiaran Masif Siarkan Penanggulangan \& Pencegahan Covid-19: Okezone Nasional." https://nasional.okezone.com/read/2020 /04/20/337/2202001/kpi-mintalembaga-penyiaran-masif-siarkanpenanggulangan-pencegahan-covid-19.

L. Dion Praditya, Supra Wimbarti, \& Avin Fadilla Helmi. "Pengaruh Tayangan Adegan Kekerasan Yang Nyata Terhadap Agresivitas.” Jurnal Psikologi 1, no. 1 (1999).

Maman Abdurahman, Sambas Ali Muhidin, Ating Somantri. Dasar-Dasar Metode Statistika Untuk Penelitian. Bandung: CV Pustaka Setia, 2011.

Muhammad, Sayyid Abdul Basit. The Spiritual Power Membangkitkan Kekuatan Paling Dahsyat Dalam Diri. Jakarta: Nakhlah Pustaka, 2008.

Nizomi, Khairin. "LITERASI MEDIA (Analisis Isi Terhadap Tayangan Televisi Pesbukers)." JIPI (Jurnal Ilmu Perpustakaan Dan Informasi) Vol.3 No.1, no. 1 (2018).

Nur Rohim Yunus \& Annissa Rezki. "Kebijakan Pemberlakuan Lockdown Sebagai Antisipasi Penyebaran Corona Virus Covid-19." Sosial \& Budaya Syar-I 7, no. 3 (2020).

Nurchayati, Zulin. "Televisi Sebagai Media Komunikasi Massa Dan Pengaruhnya." Masyarakat Telematika Dan Informasi 16, no. September (2015): 63.

Parwadi, Redatin. "Pengaruh Penggunaan Media Televisi Terhadap Penyimpangan Nilai Dan Perilaku Remaja (Kekerasan, Seks, Dan
Konsumtif) Di Kota Yogyakarta.” Jurnal Sosiohumaniora 7, no. 1 (2005).

Rijal, Syamsul. "Hipnolinguistik: Bahasa Alam Bawah Sadar.” Jurnal Pendidikan Progresif 5, no. 2 (2015).

Sri Sanityastuti, Marfuah. "Literasi Media: Upaya Menyikapi Tayangan Televisi" 7, no. 2 (2014): 25-32.

Tamama Rofiqah. "Konseling Religius: Mengatasi Rasa Kecemasan Dengan Mengadopsi Terapi Zikir Berbasis Religio Psikoneuroimunologi." Jurnal Program Studi Bimbingan Konseling 3, no. 2 (2016).

Toni, Ahmad. "Bisnis Media: Pasca Matinya Televisi Nasional Dalam Perspektif Jurnalistik.” Jurnal Komunikasi 8, no. 1 (2016): 36-50.

Utri Indah Lestari, Undang Suryatna, \& AA Kusumadinata. "Pengaruh Menonton Tayangan Ftv Kuasa Ilahi Terhadap Perilaku Masyarakat." Jurnal Komunikatio 4, no. 1 (2018).

WA, Gerungang. Psikologi Sosial. Bandung: Refika Aditama, 2009.

Wijanarko, Jarot. Hidup Produktif. Yogyakarta: ANDI, 2012.

Zahrotunnimah. "Langkah Taktis Pemerintah Daerah Dalam Pencegahan Penyebaran Virus Corona Covid-19 Di Indonesia." Sosial \& Budaya Syar-I 7, no. 3 (2020). 